Jurnal Keperawatan Silampari

Volume 5, Nomor 1, Desember 2021

e-ISSN: 2581-1975

p-ISSN: 2597-7482

DOI: https://doi.org/10.31539/jks.v5i1.2951

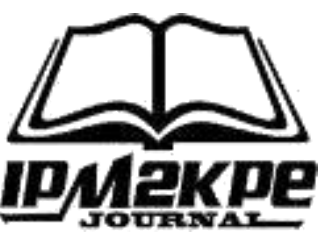

\title{
KONSELING GIZI TERHADAP PERUBAHAN PERILAKU MAKAN, INDEKS MASSA TUBUH DAN LEMAK TUBUH PADA ANAK OVERWEIGHT DAN OBESITAS
}

\author{
Rina Hasniyati ${ }^{1}$, Ismanilda ${ }^{2}$ \\ Politeknik Kesehatan Kementerian Kesehatan Padang ${ }^{1,2}$ \\ rinahasniyati43@gmail.com ${ }^{1}$
}

\begin{abstract}
ABSTRAK
Penelitian ini bertujuan untuk melihat pengaruh konseling gizi terhadap perubahan perilaku makan, indeks massa tubuh dan lemak tubuh pada anak overweight dan obesitas. Penelitian ini merupakan penelitian randomized controlled trial. Hasil penelitian diketahui bahwa persentase laki-laki lebih banyak dibandingkan perempuan yaitu 51,9 \%, sedangkan persentase umur responden paling banyak adalah 14 tahun yaitu sebanyak 46,2 \%. Simpulan, adanya perbedaan yang bemakna antara asupan energi sebelum dan sesudah pemberian konseling gizi, namun tidak ada perbedaan dengan frekuensi karbohidrat maupun frekuensi lemak. Pemberian konseling gizi dapat merubah perilaku makan berdasarkan asupan energi.
\end{abstract}

Kata Kunci: Konseling Gizi, Perilaku Makan, Obesitas, Overweight

\section{ABSTRACT}

This study aims to examine the effect of nutritional counseling on changes in eating behavior, body mass index, and body fat in overweight and obese children. This study is a randomized controlled trial. The results showed that the percentage of men was more than women, namely $51.9 \%$, while the rate of respondents' age at most was 14 years, which was $46.2 \%$. In conclusion, there is a significant difference between energy intake before and after the provision of nutritional counseling. Still, there is no difference in the frequency of carbohydrates and fat. Providing nutritional counseling can change eating behavior based on energy intake.

Keywords: Nutrition Counseling, Eating Behavior, Obesity, Overweight

\section{PENDAHULUAN}

Saat ini dunia sedang mengalami masalah gizi ganda yang dipicu oleh meningkatnya jumlah populasi dengan status gizi lebih, yaitu gemuk (overweight) dan obesitas. Prevalensi obesitas pada anak di beberapa kota besar di Indonesia berkisar 2,1 - 2,5\% dengan proporsi laki-laki lebih besar dibanding wanita (Kementerian Kesehatan, 2018a). Riskesdas tahun 2018 prevalensi gemuk pada remaja usia 13-15 tahun adalah sebesar 10,8 \% dan di Sumatera Barat sebesar 10,4 \% sedangkan Kota sebesar 9,5\%. Sekolah Menengah Pertama Islam Terpadu (SMPIT) Adzkia di kecamatan Kuranji merupakan salah satu sekolah yang memiliki kejadian overweight dan obesitas tertinggi yaitu sebesar 7,4 \% (Kementerian Kesehatan, 2018b). 
Pada tahun 1988-1994 berdasarkan Survey Kesehatan dan Status Gizi Nasional di Amerika Serikat (NHANES III), sekitar 30\% remaja dengan overweight dan obesitas mengalami sindroma metabolik. Obesitas berkontribusi dalam tingginya kolesterol, dan rendahnya LDL serta produk angiotensinogen dapat meningkatkan tekanan darah yang drastis. Produk tersebut memicu terjadinya penyakit metabolik seperti hipertensi, aterosklerosis dan dislipidemia (Xu et al., 2019). Penelitian Puryanti et al., (2021) menemukan sebagian besar responden sindrom metabolik termasuk kategori obesitas. Proses terbentuknya aterosklerosis dimulai pada dekade pertama kehidupan dan berlanjut sampai dewasa. Abnormalitas metabolik ditemukan pada penderita overweight dan obesitas.

Salah satu faktor yang dapat mempengaruhi terjadinya obesitas pada remaja adalah perilaku makan yang salah. Obesitas disebabkan adanya asupan energi berlebih (overconsumtion) yang banyak dipengaruhi faktor lingkungan. Remaja lebih suka jajan dan mencoba hal yang baru sehingga semakin tinggi untuk mencoba jajanan baru yang mengandung lemak tinggi (Ali \& Nuryani, 2018). Diet yang mengandung lemak dan kolesterol tinggi meningkatkan penumpukan lemak tubuh yang selanjutnya akan menyebabkan dislipidemia.

Body Mass Index (BMI) dianggap baik untuk menentukan overweight dan obesitas pada anak. Timbunan lemak yang berlebihan berhubungan erat dengan tingginya BMI anak. Pengukuran lemak tubuh menjadi hal yang penting sebagai upaya pencegahan terjadinya sindrom metabolik akibat obesitas. Pencegahan obesitas pada masa remaja dianggap lebih mudah dilakukan daripada menanggulangi obesitas pada usia dewasa karena mengubah kebiasaan hidup dan menurunkan berat badan yang berlebih lebih sulit dilakukan bila sudah menetap. Salah satu upaya pencegahan gizi lebih pada remaja adalah mengontrol berat badan dengan memberikan edukasi dan motivasi melalui konseling gizi. Penelitian menemukan bahwa terjadi penurunan berat badan rata-rata sebesar $1 \mathrm{~kg}$ pada remaja setelah diberikan edukasi gizi (Simbolon et al., 2018).

Konseling Gizi merupakan suatu bentuk pendekatan yang digunakan dalam asuhan gizi untuk menolong individu dan keluarga memperoleh pengertian yang lebih baik tentang dirinya serta permasalahan yang dihadapi. Edukasi gizi/konseling secara signifikan dapat meningkatkan pengetahuan remaja (Mahmudah \& Sari, 2020; Simanungkalit, 2019). Penelitian ini bertujuan melihat pengaruh konseling gizi terhadap perubahan perilaku makan, indeks massa tubuh dan lemak tubuh pada anak overweight dan obesitas. Penelitian mengenai pengaruh konseling gizi ini sudah pernah dilakukan, namun fokus pada penelitian ini adalah mengetahui pengaruh konseling gizi dengan terjadinya perubahan berat badan sampel melalui pengukuran indeks massa tubuh dan lemak tubuh.

\section{METODE PENELITIAN}

Penelitian ini merupakan penelitian eksperimen quasi experimental pre-post test control group. Sampel dalam penelitian ini adalah seluruh siswa SMPIT Adzkia yang overweight/obesitas dan memenuhi kriteria inklusi. Dari perhitungan diperoleh sampel minimal sebanyak 13 orang, selanjutnya dijadikan 2 kelompok yaitu 13 orang intervensi dan 13 orang kontrol. Teknik pengambilan sampel dilakukan dengan simple random sampling. Jenis data primer yang dikumpulkan adalah perubahan perilaku makan dengan wawancara menggunakan form sq-ffq, lemak tubuh dengan pengukuran thickness skinfold dan indeks massa tubuh anak overweight dan obesitas. Analisis data 
dengan $t$-test berpasangan apabila data terdistribusi normal dan uji Wilcoxon apabila data tidak terdistribusi normal.

\section{HASIL PENELITIAN \\ Karakteristik Responden}

Tabel. 1

Distribusi Frekuensi Sampel

Berdasarkan Jenis Kelamin dan umur

\begin{tabular}{ccc}
\hline Jenis Kelamin & $\mathrm{n}$ & $\%$ \\
\hline Perempuan & 12 & 48,1 \\
Laki-Laki & 14 & 51,9 \\
\hline Jumlah & 26 & 100 \\
\hline Umur & & 34,6 \\
12 & 9 & 15,4 \\
13 & 4 & 46,2 \\
14 & 12 & 3,8 \\
15 & 1 & 100 \\
\hline Jumlah & 26 &
\end{tabular}

Berdasarkan tabel 1 dapat diketahui bahwa persentase laki-laki lebih banyak dibandingkan perempuan yaitu 51,9 \%, sedangkan persentase umur responden paling banyak adalah 14 tahun yaitu sebanyak $46,2 \%$.

\section{Perbedaan Nilai Rata-Rata Perilaku Makan Sampel Sebelum dan Sesudah Pemberian Konseling}

Tabel. 2

Perbedaan Perilaku makan Sampel Sebelum dan Sesudah Diberikan Konseling Gizi

\begin{tabular}{lcccc}
\hline \multicolumn{1}{c}{ Analisa Perilaku makan } & $\mathrm{n}$ & Mean & SD & p-Value \\
\hline Asupan Energi Sebelum & 13 & 2.801 & 491,9 & \multirow{2}{*}{0,035} \\
Asupan Energi Sesudah & 13 & 2.631 & 371,2 & \\
\hline Frekuensi Karbohidrat sebelum & 13 & 4,5 & 1,4 & \multirow{2}{*}{0,238} \\
Frekuensi karbohidrat sesudah & 13 & 4,8 & 1,6 & \\
\hline Frekuensi Lemak sebelum & 13 & 4,4 & 2,8 & \multirow{2}{*}{0,200} \\
Frekuensi Lemak sesudah & 13 & 3,9 & 2,4 & \multirow{2}{*}{} \\
\hline
\end{tabular}

Berdasarkan tabel 2 dapat diketahui bahwa hasil uji statistik perilaku makan berdasarkan asupan energi didapatkan p-value 0,035 sedangkan berdasarkan frekuensi karbohidrat dan frekuensi lemak didapatkan p-value > 0,05 maka dapat disimpulkan bahwa ada perbedaan yang bemakna antara asupan energi sebelum dan sesudah pemberian konseling gizi $(\mathrm{p}<0,05)$, namun tidak ada perbedaan dengan frekuensi karbohidrat maupun frekuensi lemak. 


\section{Perbedaan Nilai Rata-Rata Perilaku Makan Sampel Tanpa Pemberian Konseling Gizi}

Tabel. 3

Perbedaan Perilaku makan Sampel awal dan akhir tanpa di berikan konseling Gizi

\begin{tabular}{lcccc}
\hline \multicolumn{1}{c}{ Analisa Perilaku makan } & $\mathrm{n}$ & Mean & SD & p-Value \\
\hline Asupan Energi Sebelum & 13 & $2.554,9$ & 313,5 & \multirow{2}{*}{0.770} \\
Asupan Energi Sesudah & 13 & $2.535,8$ & 367,2 & \\
\hline Frekuensi Karbohidrat sebelum & 13 & 3,7 & 0,8 & \multirow{2}{*}{0,620} \\
Frekuensi karbohidrat sesudah & 13 & 3,9 & 1,1 & \\
\hline Frekuensi Lemak sebelum & 13 & 3,3 & 1,5 & \multirow{2}{*}{0,679} \\
Frekuensi Lemak sesudah & 13 & 3,2 & 1,0 & \\
\hline
\end{tabular}

Berdasarkan tabel 3 dapat diketahui bahwa hasil uji statistik perilaku makan berdasarkan asupan energi, frekuensi karbohidrat dan frekuensi lemak didapatkan nilai $\mathrm{p}$ value $>0,05$ maka dapat disimpulkan bahwa tidak ada perbedaan yang bermakna antara perilaku makan diawal dan di akhir tanpa pemberian konseling gizi.

\section{Perbedaan Perubahan Perilaku Makan Sampel antara Diberikan Konseling Gizi dan Tidak Diberikan Konseling Gizi}

Tabel. 4

Perbedaan Perubahan Perilaku Makan antara Sampel yang Diberikan Konseling Gizi dan Tidak Diberikan Konseling Gizi

\begin{tabular}{lccccc}
\hline \multicolumn{1}{c}{ Intervensi } & & $\mathrm{n}$ & Mean & SD & p-Value \\
\hline Konseling gizi & Asupan & 13 & 2631,1 & 371,2 & \multirow{2}{*}{0.517} \\
Tidak konseling gizi & energi & 13 & 2535,8 & 367,2 & \\
\hline Konseling gizi & Frekuensi & 13 & 4,8 & 1,6 & \multirow{2}{*}{0,102} \\
Tidak konseling gizi & karbohidrat & 13 & 3,9 & 1,1 & \\
\hline Konseling gizi & Frekuensi & 13 & 3,9 & 2,4 & \multirow{2}{*}{0,320} \\
Tidak konseling gizi & lemak & 13 & 3,2 & 1,0 & \\
\hline
\end{tabular}

Berdasarkan tabel 4 dapat diketahui bahwa hasil uji statistik didapatkan p-value > 0.05 maka dapat disimpulkan bahwa tidak ada perbedaan yang bermakna perubahan perilaku makan sampel antara yang diberikan konseling dan tidak diberikan konseling gizi $(\mathrm{p}<0.05)$.

PerbedaanNilai Rata-Rata Indeks Massa Tubuh (IMT) Sampel Sebelum dan Sesudah Pemberian Konseling

Tabel. 5

Perbedaan IMT Sampel Sebelum dan Sesudah Diberikan Konseling Gizi

\begin{tabular}{ccccc}
\hline Analisa IMT & $\mathrm{n}$ & Mean & SD & p-Value \\
\hline IMT Sebelum & 13 & 24,6 & 1,77 & \multirow{2}{*}{0.337} \\
IMT Sesudah & 13 & 24,7 & 1,86 & \\
\hline
\end{tabular}


Berdasarkan tabel 5 dapat diketahui bahwa hasil uji statistik didapatkan p value 0.337 maka dapat disimpulkan bahwa tidak ada perbedaan yang bemakna antara IMT sebelum dan sesudah pemberian konseling gizi $(\mathrm{p}>0.05)$.

\section{Perbedaan Nilai Rata-Rata Imt Sampel Tanpa Pemberian Konseling Gizi}

Tabel. 6

Perbedaan IMT Sampel Sebelum

dan Sesudah Tanpa Diberikan Konseling Gizi

\begin{tabular}{ccccc}
\hline Analisa IMT & $\mathrm{n}$ & Mean & SD & p-Value \\
\hline IMT Sebelum & 13 & 23,3 & 2,19 & \multirow{2}{*}{0.061} \\
IMT Sesudah & 13 & 23,9 & 1,99 & \\
\hline
\end{tabular}

Berdasarkan tabel 6 dapat diketahui bahwa hasil uji statistik didapatkan p-value 0.061 maka dapat disimpulkan bahwa tidak ada perbedaan yang bermakna antara IMT diawal dan di akhir tanpa pemberian konseling gizi ( $\mathrm{p}>0.05)$.

\section{Perbedaan Perubahan Imt Sampel antara Diberikan Konseling Gizi dan Tidak Diberikan Konseling Gizi}

Tabel. 7

Perbedaan Perubahan IMT antara Sampel yang Diberikan Konseling Gizi dan Tidak Diberikan Konseling gizi

\begin{tabular}{lcccc}
\hline \multicolumn{1}{c}{ Intervensi } & $\mathrm{n}$ & Mean & SD & p-Value \\
\cline { 1 - 4 } Konseling gizi & 13 & 24,7 & 1,86 & \multirow{2}{*}{0.296} \\
\hline Tidak konseling gizi & 13 & 23,9 & 1,99 & \\
\hline
\end{tabular}

Berdasarkan tabel 7 dapat diketahui bahwa hasil uji statistik didapatkan p-value 0.296 maka dapat disimpulkan bahwa tidak ada perbedaan yang bermakna perubahan IMT sampel antara yang diberikan konseling dan tidak diberikan konseling gizi $(\mathrm{p}>0.05)$.

\section{Perbedaan Nilai Rata-Rata Persen Lemak Tubuh Sampel Sebelum Dan Sesudah Pemberian Konseling}

Tabel. 8

Perbedaan Persen Lemak Tubuh Sampel sebelum dan Sesudah Diberikan Konseling Gizi

\begin{tabular}{ccccc}
\hline Analisa persen Lemak Tubuh & $\mathrm{n}$ & Mean & SD & p-Value \\
\hline Persen lemak tubuh Sebelum & 13 & 31,9 & 3,76 & \multirow{2}{*}{0.678} \\
Persen lemak tubuh Sesudah & 13 & 31,6 & 2,78 & \\
\hline
\end{tabular}

Berdasarkan tabel 8 dapat diketahui bahwa hasil uji statistik didapatkan p-value 0.678 maka dapat disimpulkan bahwa tidak ada perbedaan yang bemakna antara persen lemak tubuh sebelum dan sesudah pemberian konseling gizi $(\mathrm{p}<0.05)$. 


\section{Perbedaan Nilai Rata-Rata Persen Lemak Tubuh Sampel Tanpa Pemberian Konseling Gizi}

Tabel. 9

Perbedaan Persen Lemak Tubuh Sampel sebelum dan Sesudah tanpa Diberikan Konseling Gizi

\begin{tabular}{ccccc}
\hline Analisa Persen lemak tubuh & $\mathrm{n}$ & Mean & SD & p-Value \\
\hline Persen lemak tubuh Sebelum & 13 & 31,6 & 1,89 & \multirow{2}{*}{0.586} \\
Persen lemak tubuh Sesudah & 13 & 31,5 & 1,86 & \\
\hline
\end{tabular}

Berdasarkan tabel 9 dapat diketahui bahwa hasil uji statistik didapatkan p-value 0.586 maka dapat disimpulkan bahwa tidak ada perbedaan yang bermakna antara persen lemak tubuh diawal dan di akhir tanpa pemberian konseling gizi $(\mathrm{p}<0.05)$.

\section{Perbedaan Perubahan Persen Lemak Tubuh Sampel antara Diberikan Konseling Gizi dan Tidak Diberikan Konseling Gizi}

Tabel. 10

Perbedaan Perubahan Persen Lemak Tubuh antara Sampel yang Diberikan Konseling Gizi dan Tidak Diberikan Konseling Gizi

\begin{tabular}{lcccc}
\hline \multicolumn{1}{c}{ Intervensi } & $\mathrm{n}$ & Mean & SD & p-Value \\
\hline Konseling gizi & 13 & 31,7 & 2,78 & \multirow{2}{*}{0.877} \\
Tidak konseling gizi & 13 & 31,6 & 1,86 & \\
\hline
\end{tabular}

Berdasarkan tabel 10 dapat diketahui bahwa hasil uji statistik didapatkan p-value 0.877 maka dapat disimpulkan bahwa tidak ada perbedaan yang bermakna perubahan persen lemak tubuh sampel antara yang diberikan konseling dan tidak diberikan konseling gizi $(\mathrm{p}<0.05)$.

\section{PEMBAHASAN}

Perilaku Makan

Berdasarkan hasil penelitian dapat dilihat bahwa sebelum dilakukan konseling gizi rata-rata asupan energi adalah sebesar $2.801 \mathrm{kkal}$, sedangkan sesudah adalah sebesar 2631 kkal. Hasil uji statistik perilaku makan berdasarkan asupan energi didapatkan nilai $\mathrm{p}$ value 0,035 , maka dapat disimpulkan bahwa ada perbedaan yang bermakna antara asupan energi sebelum dan sesudah pemberian konseling gizi. Hal ini disebabkan karena sampel sudah berusaha menerapkan konseling gizi yang diberikan dengan mengubah perilaku makan. Sampel mematuhi aturan jumlah makan sesuai kebutuhan yang sudah disusun dan diberikan kepada sampel. Sejalan dengan penelitian Imbar et al., (2019) menunjukkan bahwa asupan energi sebelum diberikan konseling gizi rata-rata 2445 kkal $\pm 1,8$ sesudah diberikan konseling $2342 \mathrm{kkal} \pm 1,9$, terjadi penurunan $103 \mathrm{kkal}$.

Obesitas disebabkan adanya asupan energi berlebih (overconsumtion) yang banyak dipengaruhi faktor lingkungan (Sineke et al., 2019). Orang yang obesitas biasanya lebih responsif dibanding dengan orang yang memiliki berat badan normal terhadap isyarat lapar eksternal seperti rasa dan bau makanan atau saatnya waktu makan. Mereka cenderung makan bila ia merasa ingin makan, bukan makan pada saat lapar. Perilaku makan yang berlebihan inilah menyebabkan mereka sulit untuk keluar dari kegemukan apabila tidak memiliki kontrol diri dan motivasi kuat untuk mengurangi 
berat badan. Penelitian Hafiza et al., (2019) menunjukkan bahwa $85.5 \%$ remaja mempunyai kebiasaan makan yang kurang baik. Penelitian Amir \& Adi (2018) juga menemukan bahwa tingkat kecukupan energi yang lebih dari $77 \%$ AKG pada remaja dengan status gizi lebih sebesar $91.4 \%$.

Kebiasaan makan merupakan kebiasaan dalam memilih jenis, jumlah dan frekuensi makan yang dikonsumsi serta cara memilih makanan. Remaja lebih suka jajan dan mencoba hal yang baru sehingga semakin tinggi untuk mencoba jajanan yang baru. Kebiasaan jajanan remaja adalah makanan gorengan, minuman berwarna dan makanan tinggi lemak. Peran orang tua sangat penting dalam membentuk kebiasaan makan anak. Pada saat anak beranjak remaja faktor lingkungan, teman sebaya dan kehidupan sosial diluar rumah sangat berpengaruh terhadap kebiasaan makannya. Faktor eksternal seperti dukungan keluarga dan food environment mempengaruhi perilaku konsumsi (Safitri \& Rahayu, 2020). Banyak ditemukan remaja menyukai makanan cepat saji yang tinggi lemak dan karbohidrat. Kebiasaan makan tinggi lemak, karbohidrat menjadi penyebab masalah gizi lebih (Ali \& Nuryani, 2018). Pengaturan asupan makan dipengaruhi oleh sistem neuroendokrin yang dikontrol oleh sistem saraf pusat. Hormon yang terlibat dalam pengaturan makan yaitu leptin dan ghrelin. Leptin akan memberikan efek penghambatan untuk makan dengan memberikan sinyal rasa kenyang ke sistem saraf pusat. Sedangkan ghrelin memiliki pengaruh dalam meningkatkan nafsu makan (Utami et al., 2018).

Tindakan atau perilaku merupakan suatu kegiatan atau aktivitas seseorang. Sedangkan dari segi kepentingan kerangka analisis, tindakan adalah apa yang dikerjakan oleh seseorang. Terbentuknya perilaku seseorang dimulai dari adanya stimulus sehingga menimbulkan pengetahuan, dalam faktor pendukung bila manfaat sudah diketahui melalui informasi yang didapat maka seseorang akan mempunyai sikap yang positif dan mempunyai niat untuk melakukan tindakan melalui dukungan sosial. Pengetahuan gizi merupakan pengetahuan tentang makanan dan zat gizi, makanan yang aman dikonsumsi dan cara mengolah makanan yang baik. Konseling secara signifikan dapat meningkatkan pengetahuan remaja dengan perbedaan rata-rata sebelum dan setelah konseling sebesar 2.41\% (Simbolon et al., 2018). Beberapa penelitian menunjukkan ada hubungan yang signifikan antara pengetahuan gizi dengan kejadian gizi lebih pada remaja (Amanda et al., 2021; Simanungkalit, 2019). Penelitian lain yang dilakukan oleh Angraini et al., (2019) menyatakan bahwa ada perbedaan nyata perilaku memilih jajanan sehat siswa sekolah dasar sebelum dan sesudah penyuluhan.

Berdasarkan hasil penelitian juga diketahui bahwa sebelum dilakukan konseling gizi rata-rata frekuensi lemak adalah 3,3 dan sesudah konseling 3,2, sedangkan frekuensi karbohidrat sebelum adalah 3,7 dan sesudah konseling adalah 3,9. Rata-rata frekuensi lemak menurun setelah diberikan konseling gizi namun tidak memperlihatkan perbedaan ( $\mathrm{p}$-value > 0,05). Hal ini disebabkan karena rata-rata sampel sudah mulai memperhatikan jenis bahan makanan yang dikonsumsinya, terutama dengan mengurangi penggunaan makanan sumber lemak. Sejalan dengan penelitian Imbar et al., (2019) yang mendapatkan rata-rata asupan lemak sesudah diberikan konseling mengalami penurunan.

Berdasarkan hasil penelitian didapatkan bahwa rata-rata frekuensi karbohidrat meningkat dengan hasil uji statistik didapatkan $\mathrm{p}$ value $>0,05$ yang berarti tidak ada perbedaan yang bermakna perubahan perilaku makan berdasarkan frekuensi karbohidrat antara diberikan konseling gizi atau tidak $(\mathrm{p}>0.05)$. Hal ini dikarenakan meskipun beberapa siswa dari kelompok perlakuan dan kelompok kontrol ada yang mengalami 
perubahan frekuensi karbohidrat, namun masih banyak pula sampel yang memiliki perilaku konsumsi karbohidrat yang berlebih. Hasil penelitian Amir \& Adi (2018) menunjukkan bahwa sebagian besar $(71.4 \%)$ remaja dengan status gizi lebih mempunyai tingkat kecukupan karbohidrat $>77 \%$ AKG. Hasil penelitian ini yaitu kelompok yang diberikan konseling dan tidak diberikan konseling sama-sama tidak memiliki perbedaan dalam hal merubah perilaku makan berdasarkan frekuensi karbohidrat dan frekuensi lemak. Hal ini disebabkan karena banyak faktor lain yang mempengaruhi seseorang dalam merubah perilaku makannya. Salah satu faktor yang menjadi hambatan perubahan perilaku ini adalah aktifitas sampel yang lebih banyak dilakukan di dalam rumah saat ini. Kondisi wabah covid 19 saat ini membuat siswa belajar secara daring dan cenderung mengkonsumsi makanan berulang kali (frekuensi makan meningkat) untuk menemani masa belajar.

\section{Indeks Massa Tubuh (IMT) dan Persen Lemak Tubuh}

Hasil penelitian menunjukkan bahwa nilai rata-rata IMT sebelum pemberian konseling gizi adalah 24,6 dan sesudah konseling 24,7 dengan hasil uji statistik didapatkan nilai $\mathrm{p}$ value 0.337. Hal tersebut dapat disimpulkan bahwa tidak ada perbedaan yang bemakna antara IMT sebelum dan sesudah pemberian konseling gizi (p>0.05). Sejalan dengan penelitian Demsa Simbolon et al., (2018) yang mendapatkan bahwa tidak terdapat perbedaan rata-rata berat badan remaja sebelum dan sesudah diberikan edukasi. Hal ini disebabkan oleh banyak faktor terjadinya kegemukan, yaitu faktor genetik, kesehatan, psikologis, prilaku makan, aktifitas fisik dan pengetahuan tentang gizi. Pendidikan gizi merupakan suatu upaya mendidik remaja untuk merubah perilaku yang benar-benar dapat diimplementasikan dalam kehidupan sehari-hari (Lestantina, 2018).

Penelitian juga mendapatkan rata-rata persen lemak tubuh sebelum pemberian konseling gizi adalah sebesar 31,9\% turun menjadi 31,6\% setelah pemberian konseling. Walaupun kategori persen lemak tubuhnya masih dalam kategori berlebih $(\geq$ $30 \%$ ), namun sudah mengalami penurunan sebesar $\pm 0,3 \%$. Obesitas merupakan hasil dari proses yang berjalan menahun, sehingga penanganannya tidak akan efektif hanya dalam waktu singkat.

Lemak tubuh memiliki hubungan yang erat dengan IMT karena nilai IMT yang tinggi dapat mengindikasi lemak tubuh yang lebih tinggi. Penelitian Handayani et al., (2019) menunjukkan bahwa terdapat hubungan signifikan antara status gizi berdasarkan IMT/U dengan persen lemak tubuh. Sejalan dengan penelitian Puryanti et al., (2021) mendapatkan nilai OR pada uji statistik IMT menunjukkan 3,444 kali bahwa seseorang tidak obesitas memiliki peluang tidak menderita sindrom metabolik. Pemberian konseling gizi memberikan dampak penurunan IMT dan persen lemak tubuh, walaupun secara statistik tidak dapat membuktikan perbedaan pengaruh konseling terhadap IMT ataupun persen lemak tubuh. Pemberian konseling yang efektif dilakukan salah satunya melalui pendekatan kepada remaja beserta orang-orang terdekatnya baik itu orang tua, guru atau teman dekat. Intervensi terhadap remaja overweight dan obesitas dilakukan melalui Usaha Kesehatan Sekolah (UKS) dengan melibatkan orang tua sehingga permasalahan dapat diselesaikan secara komprehensif (Dwijayanto, 2021). 


\section{SIMPULAN}

Adanya perbedaan yang bemakna antara asupan energi sebelum dan sesudah pemberian konseling gizi, namun tidak ada perbedaan dengan frekuensi karbohidrat maupun frekuensi lemak. Pemberian konseling gizi dapat merubah perilaku makan berdasarkan asupan energi.

\section{SARAN}

Sekolah sebagai institusi pendidikan yang menjalankan Upaya Kesehatan Sekolah (UKS) bersama dengan pelayanan kesehatan bekerja sama dalam memberikan pelayanan kesehatan preventif secara berkala kepada remaja. Melakukan penilaian status gizi dengan memonitoring indeks massa tubuh remaja serta memberikan edukasi untuk meningkatkan pengetahuan. Selain itu juga perlu peran aktif orang tua untuk menyediakan makanan yang sehat dengan gizi seimbang.

\section{DAFTAR PUSTAKA}

Ali, R., \& Nuryani, N. (2018). Sosial Ekonomi, Konsumsi Fast Food dan Riwayat Obesitas sebagai Faktor Risiko Obesitas Remaja. Media Gizi Indonesia, 13(2), 123-132. DOI: 10.20473/mgi.v13i2.123-132

Amanda, I. G. A., Putri, A., Veronica, E., Olivia, F., Pasaribu, M. R., \& Sutiari, N. K. (2021). Potensi Permainan Papan Edukasi Aktif Kutus PHBS sebagai Modalitas Pencegahan Obesitas pada Anak. Jurnal Ilmiah Kesehatan Sandi Husada, 10(1), 139-146. DOI: 10.35816/jiskh.v10i1.545

Amir, R. A., \& Adi, A. C. (2018). Gambaran Aktivitas Sedentari dan Tingkat Kecukupan Gizi pada Remaja Gizi Lebih dan Gizi Normal. Media Gizi Indonesia, 12(1), 80. DOI: 10.20473/mgi.v12i1.80-87

Angraini, W., Betrianita, B., Pratiwi, B. A., Yanuarti, R., \& Fermana, P. (2019). Pengaruh Pendidikan Kesehatan terhadap Pengetahuan, Sikap, dan Frekuensi Konsumsi Makanan Jajanan. Jurnal Kesmas Asclepius, 1(1), 1-13. DOI: 10.31539/jka.v1i1.605

Dwijayanto, I. M. R. (2021). Peran Upaya Kesehatan Sekolah (UKS) dalam Upaya Penanggulangan Obesitas pada Siswa SMA Negeri 2 Negara. Jurnal Media Keperawatan, 12(21), 111-116. http://journal.poltekkesmks.ac.id/ojs2/index.php/mediakeperawatan/article/view/2153

Hafiza, D., Utmi, A., \& Niriyah, S. (2021). Hubungan Kebiasaan Makan dengan Status Gizi pada Remaja Smp YLPI Pekanbaru. Al-Asalmiya Nursing Jurnal Ilmu Keperawatan (Journal of Nursing Sciences), 9(2), 86-96. DOI: 10.35328/keperawatan.v9i2.671

Handayani, S., Kapota, W. N., \& Oktavianto, E. (2019). Hubungan Status Asi Eksklusif dengan Kejadian Stunting pada Batita Usia 24-36 Bulan di Desa Watugjah Kabupaten Gunungkidul. Medika Respati Jurnal Ilmiah Kesehatan, 14(4), 287300. http://dx.doi.org/10.35842/mr.v14i4.226

Imbar, H. S., Sineke, J., \& Rugian, C. (2019). Pengaruh Konseling Gizi pada Asupan Makan Remaja Obesitas di SMP Kristen Woloan Kota Tomohon. Jurnal GIZIDO, 11(01), 23-27. DOI: 10.47718/gizi.v11i01.751

Kementerian Kesehatan. (2018a). Hasil Utama Riset Kesehata Dasar (RISKESDAS). in Riskesdas. Jakarta, pp. 1-200. DOI: 10.1088/1751-8113/44/8/085201

Kementerian Kesehatan. (2018b). Riskesdas dalam Angka Propinsi Sumatera Barat. in. Jakarta: Kemenkes RI 
Lestantina, A. (2018). Konseling Gizi pada Remaja Obesitas. Jurnal Media Kesehatan, 11(1), 071-078. DOI: 10.33088/jmk.v11i1.359

Mahmudah, U., \& Sari, S. P. (2020). Pengaruh Penggunaan Media Cakram Gizi terhadap Pengetahuan Remaja Mengenai Konsumsi Buah dan Sayur. Ilmu Gizi Indonesia, 3(2), 155. DOI: 10.35842/ilgi.v3i2.142

Puryanti, N. M., Ilmi, I. M. B., \& Maryusman, T. (2021). Hubungan Asupan Zat Gizi Makro dan IMT dengan Sindrom Metabolik pada Pegawai Perusahaan Tambang. Indonesian Journal of Health Development, 3(1), 193-200. https://ijhd.upnvj.ac.id/index.php/ijhd/article/view/83

Safitri, D. E., \& Rahayu, N. S. (2020). Determinan Status Gizi Obesitas pada Orang Dewasa di Perkotaan: Tinjauan Sistematis. ARKESMAS (Arsip Kesehatan Masyarakat), 5(1), 1-15. DOI: 10.22236/arkesmas.v5i1.4853

Simanungkalit, S. F. (2019). Determinan Gizi Lebih pada Remaja di SMP YPI Bintaro Jakarta. Jurnal Ilmu Kesehatan Masyarakat, 8(01), 25-29. DOI: 10.33221/jikm.v8i01.185

Simbolon, D., Tafrieani, W., \& Dahrizal, D. (2018). Edukasi Gizi dan Perubahan Berat Badan Remaja Overweight dan Obesitas. Jurnal Kesehatan, 9(2), 289. DOI: 10.26630/jk.v9i2.841

Sineke, J., Kawulusan, M., Purba, R. B., \& Dolang, A. (2019). Hubungan Tingkat Pengetahuan Gizi dan Pola Makan dengan Kejadian Obesitas pada Siswa SMK Negeri 1 Biaro', Jurnal GIZIDO, 11(01), 28-35. DOI: 10.47718/gizi.v11i01.752

Utami, N. P., Purba, M. B., \& Huriyati, E. (2018). Paparan Screen Time Hubungannya dengan Obesitas pada Remaja SMP di Kota Yogyakarta. Jurnal Dunia Gizi, 1(2), 71-78. https://ejournal.helvetia.ac.id/jdg

Xu, H., Li, X., Adams, H., Kubena, K., \& Guo, S. (2019). Etiology of Metabolic Syndrome and Dietary Intervention. International Journal of Molecular Sciences, 20(128), 1-19. DOI: 10.3390/ijms20010128 